\title{
IDENTIFIKASI BIDANG GELINCIR BERDASARKAN PARAMETER FISIKA BATUAN (STUDI KASUS: DAERAH RAWAN LONGSOR DI JALAN KERETA API KM 110, PURWAKARTA)
}

\author{
BUDY SANTOSO *, BAMBANG WIJATMOKO, EDDY SUPRIYANA \\ Departemen Geofisika, FMIPA, Universitas Padjadjaran \\ Jl. RayaBandung-Sumedang Km.21 Jatinangor 45363, \\ Sumedang, Jawa Barat, Telp. 022-7792435 \\ *email : budi@geophys.unpad.ac.id
}

\begin{abstract}
Abstrak. Jalan Kereta Api Km 110, Purwakarta, Jawa Barat adalah salah satu lokasi yang rawan pergerakan tanah. Salah satu faktor yang menyebabkan gerakan tanah di lokasi ini adalah adanya bidang gelincir yang berada di bawah permukaan tanah. Gerakan tanah di lokasi ini merupakan gerakan tanah lama yang aktif kembali karena dipicu oleh infiltrasi air hujan. Secara geologi daerah penelitian termasuk dalam Formasi Subang, terdiri dari: batulempung, breksi dan batupasir. Batulempung merupakan lapisan kedap air, apabila terdapat infiltrasi air hujan, maka air tidak dapat diserap oleh lapisan batuan tersebut, tetapi akan mengalir ke arah bawah lereng. Batulempung yang terkena air akan mengubah sifat kekerasan batulempung menjadi licin, sehingga permukaan batulempung tersebut dapat berfungsi sebagai bidang gelincir. Berdasarkan hasil pengukuran resistivitas, data pengeboran dan analisis laboratorium mekanika tanah, Batulempung memiliki nilai resistivitas: $1-5 \Omega \mathrm{m}$, permeabilitas: $5,39 \times 10^{-7} \mathrm{~cm} /$ detik dan porositas: $54,99 \%$.
\end{abstract}

Kata kunci: bidang gelincir, permeabilitas, porositas, resistivitas

\begin{abstract}
Railroad Km 110, Purwakarta, West Java is an area prone to land movements. One of the factors causing the land movement in this area is the existence of a sliding plane that is below the surface of the soil. The land movement at this location is an old land movement that is active again because it was triggered by rainwater infiltration. Geologically the study area is included in the Subang Formation, consisting of: claystone, breccias and sandstones. Claystone is a water impermeable layer, if there is rainwater infiltration, then the water cannot be absorbed by the rock layer, but it will flow downward in the direction of the slope. Clay stone that are exposed to water will change the violent nature of the rocks to be soft and slippery, so that the clay stone's surface can function as a sliding plane. Based on the results of resistivity measurements, drilling data and soil mechanics laboratory analysis, Clay stone has resistivity values: $1-5 \Omega \mathrm{m}$, permeability: $5,39 \times 10^{-7} \mathrm{~cm} / \mathrm{sec}$ and porosity: $54,99 \%$.
\end{abstract}

Keywords: sliding plane, permeability, porosity, resistivity

\section{Pendahuluan}

Penelitian ini dilakukan disekitar jalan kereta api Km.110, Purwakarta, Jawa Barat, Indonesia. Secara umum kondisi geografis daerah penelitian berada di daerah pegunungan dan perbukitan yang mempunyai potensi longsor. Longsor adalah fenomena geologi yang terjadi karena pergerakan material pembentuk lereng berupa tanah, batuan, atau kombinasi jenis material tersebut, ke tempat yang lebih rendah karena pengaruh gaya gravitasi [1]. Lereng yang mengandung lapisan tanah 
jenuh air akibat infiltrasi air hujan akan menyebabkan berkurangnya kuat geser dan peningkatan tegangan geser tanah [2,3], sehingga lereng menjadi tidak stabil dan akhirnya terjadi longsor [4].

Berdasarkan Peta Kerentanan Gerakan Tanah, Kab. Purwakarta [5], daerah penelitian termasuk kedalam zona kerentanan gerakan tanah menengah-tinggi. Pada zona ini dapat terjadi gerakan tanah disebabkan daerah yang berbatasan dengan lembah, sungai, gawir, tebing jalan atau lereng yang mengalami gangguan akibat pengaruh infiltrasi air hujan. Berdasarkan geologi regional daerah Purwakarta termasuk ke dalam Formasi Subang [6], batuan penyusunnya terdiri atas: Batupasir, andesit, breksi, batupasir konglomerat dan batulempung. Batulempung merupakan salah satu batuan yang dapat berfungsi sebagai bidang gelincir ketika terjadi longsor. Salah satu pemicu longsor yaitu infiltrasi air hujan yang akan mengaktifkan bidang gelincir pada batuan yang bersifat kedap air (impermeable). Bidang gelincir di daerah penelitian terdapat pada batas permukaan batulempung dengan batuan yang ada diatasnya yang bersifat porus (memiliki permeabilitas tinggi).

Beberapa penelitian terdahulu untuk mengidentifikasi potensi longsor telah dilakukan menggunakan metode Electrical Resistivity Tomography [7,8,9]. Penelitian-penelitian tersebut masih membahas gerakan tanah secara umum, sedangkan pembahasan khusus tentang arah dan sudut bidang gelincir secara spesifik untuk lokasi penelitian belum banyak dibahas padahal info ini juga penting untuk mitigasi.

\section{Metode Penelitian}

Metode yang digunakan dalam penelitian ini adalah Metode Electrical Resistivity Tomography (ERT). Metode ERT adalah metode pengukuran resistivitas di permukaan tanah dengan menggunakan banyak elektroda, agar diperoleh variasi distribusi resistivitas bawah permukaan [10]. Pemilihan Metode ERT dalam penelitian ini didasarkan pertimbangan bahwa metode tersebut memiliki resolusi resistivitas secara lateral dan vertikal yang sangat baik, sehingga dapat mendeteksi bidang gelincir dan pergeseran yang terjadi pada lapisan batuan. Dalam pengukuran ERT dilokasi penelitian, panjang lintasan yang diukur adalah $240 \mathrm{~m}-300 \mathrm{~m}$ dengan jarak antar elektroda 7,5 m dan jumlah elektroda 41 buah. Skema pengukuran Electrical Resistivity Tomography (ERT) ditunjukkan pada Gambar 1.

Besarnya resistivitas $(\rho)$ dalam pengukuran ERT dapat dihitung dengan persamaan rumus dibawah ini :

$$
\rho=K \frac{\Delta V}{I}
$$

Parameter K disebut faktor geometri. Faktor geometri merupakan besaran koreksi terhadap perbedaan letak susunan elektroda arus dan potensial. Nilai faktor geometri ini ditentukan oleh jenis konfigurasi elektroda yang akan digunakan. Konfigurasi elektroda yang digunakan dalam pengukuran resistivitas (ERT), yaitu konfigurasi Dipole-Dipole. Persamaan untuk menghitung resistivitas semu dengan Konfigurasi Dipole-Dipole [11] sebagai berikut: 


$$
\rho_{s}=n(n+1)(n+2) \pi a \frac{\Delta V}{I}
$$

dengan, $\rho_{\mathrm{s}}$ : resistivitas semu $(\Omega \mathrm{m}), \Delta \mathrm{V}$ : beda potensial $(\mathrm{V}), \mathrm{I}$ : arus yang diinjeksikan (A), dan a : jarak antara pasangan elektroda arus dan elektroda potensial (m). Nilai resistivitas semu yang diperoleh dalam pengukuran ERT, selanjutnya digunakan sebagai data masukkan untuk pemodelan resistivitas dengan Metode Inversi Least-Square [12].

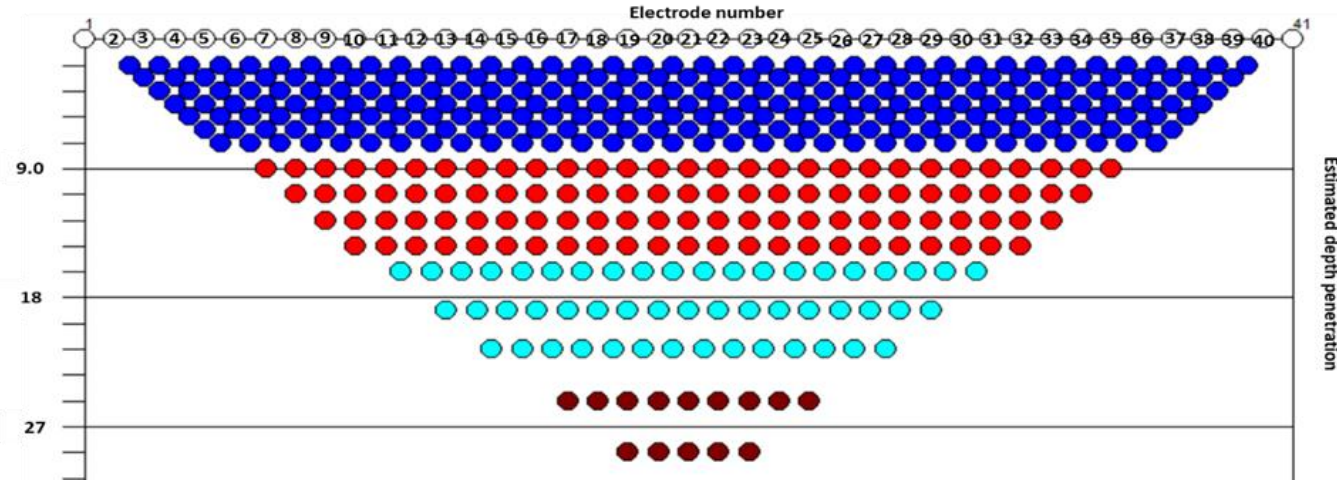

Gambar 1. Skema pengukuran Electrical Resistivity Tomography (ERT) menggunakan Konfigurasi Dipole-Dipole dengan 41 elektroda (I : elektroda arus, V : elektroda potensial)

Peralatan yang digunakan dalam penelitian ini, yaitu: resistivity meter Naniura 300 Hf yang dilengkapi dengan switch box 41 elektroda yang dapat digunakan untuk pengukuran resistivitas dengan Metode ERT, mesin bor serta cooring untuk validasi jenis batuan. Pengukuran resistivitas dilakukan sebanyak 4 lintasan pengukuran, terdiri dari: 2 lintasan sejajar rel kereta api dan 2 lintasan tegak lurus rel kereta api. Posisi dari masing-masing lintasan pengukuran ERT ditunjukkan pada Gambar 2. Pada lintasan pengukuran resistivitas (ERT) dilakukan pemboran sebanyak 2 titik, yaitu:

- Titik Bor BM-01, terletak di jalan kereta api Km-110, di kaki tebing dengan jarak $45 \mathrm{~m}$ dari pilar jembatan kereta api

- Titik Bor BM-02, terletak di jalan kereta api Km-110, jarak 4 m di samping jembatan kereta ke arah Bandung

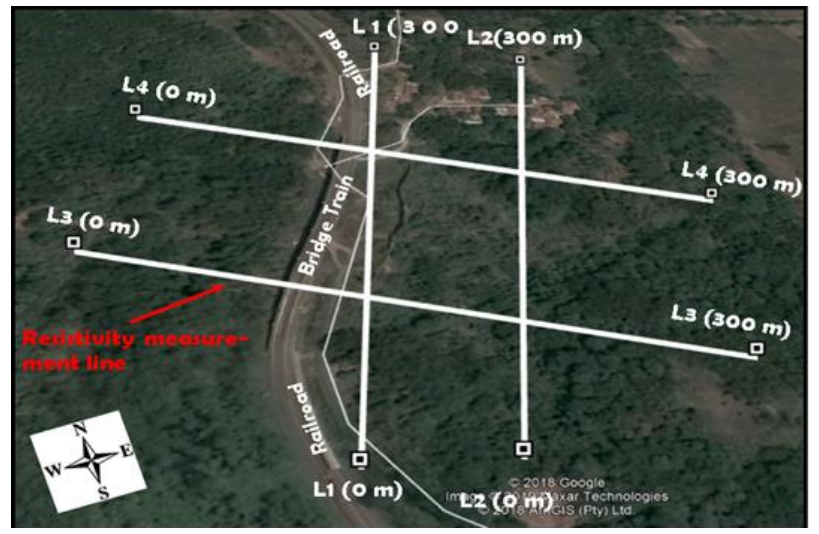

Gambar 2. Peta Lintasan Pengukuran Resistivitas 
Sampel batuan yang diperoleh dari hasil pemboran selanjutnya di analisis di Laboratorium Mekanika Tanah, sedangkan parameter batuan yang diuji yaitu: porositas dan permeabilitas.

\section{Hasil dan Pembahasan}

Berdasarkan hasil pemodelan resistivitas diperoleh 4 buah penampang resistivitas2D dengan nilai resistivitas yang berkisar antara: $1-70 \Omega \mathrm{m}$, range nilai resistivitas batuan menunjukkan jenis batuan. Untuk menghindari ambiguitas ketika interpretasi, maka dilakukan pemboran sebanyak 2 titik sampai dengan kedalaman 30 meter untuk mengidentifikasi jenis batuan (Tabel 1) dan analisis sampel batuan (porositas dan permeabilitas) di Laboratorium Mekanika Tanah (Tabel 2).

Tabel 1. Data Pemboran dan Standard Penetration Test (SPT)

\begin{tabular}{|c|c|c|c|c|c|}
\hline $\begin{array}{l}\text { Titik } \\
\text { Bor }\end{array}$ & Lokasi & $\begin{array}{l}\text { Kedalaman } \\
(\mathbf{m})\end{array}$ & Jenis batuan & $\begin{array}{c}\text { SPT } \\
(\mathbf{N})\end{array}$ & $\begin{array}{c}\text { Muka } \\
\text { Air } \\
\text { Tanah }\end{array}$ \\
\hline $\begin{array}{l}\text { BM- } \\
01\end{array}$ & $\begin{array}{l}\text { Jalan kereta api Km- } \\
110 \text {, di kaki tebing } \\
\text { dengan jarak } 45 \mathrm{~m} \text { dari } \\
\text { pilar jembatan kereta } \\
\text { api }\end{array}$ & $\begin{array}{l}0-4 \\
4-4.5 \\
4,5-6 \\
6-30\end{array}$ & $\begin{array}{l}\text { Lempung (tidak padat) } \\
\text { Pasir kasar (kurang padat) } \\
\text { Batupasir halus (padat) } \\
\text { Batulempung(padat), } \\
\text { kedalaman 19m terdapat } \\
\text { sisipan breksi. }\end{array}$ & $\begin{array}{c}6 \\
25 \\
25- \\
57 \\
>60\end{array}$ & $4 \mathrm{~m}$ \\
\hline $\begin{array}{l}\text { BM- } \\
02\end{array}$ & $\begin{array}{l}\text { Jalan kereta api Km- } \\
110 \text {, jarak } 4 \mathrm{~m} \text { di } \\
\text { samping jembatan } \\
\text { kereta ke arah } \\
\text { Bandung. }\end{array}$ & $\begin{array}{l}0-4 \\
4-11 \\
11-17 \\
17-30\end{array}$ & $\begin{array}{l}\text { Lempung (tidak padat) } \\
\text { Pasir kasar (kurang padat) } \\
\text { Batupasir halus (padat) } \\
\text { Batulempung (padat) }\end{array}$ & $\begin{array}{c}6 \\
25 \\
25- \\
57 \\
>60\end{array}$ & $4 \mathrm{~m}$ \\
\hline
\end{tabular}

Dalam melakukan interpretasi diperlukan nilai resistivitas referensi yang diperoleh dari korelasi penampang resistivitas lintasan 3 dan lintasan 4 dengan data bor BM01 dan BM-02. Berdasarkan hasil korelasi tersebut, maka diperoleh nilai resistivitas batuan daerah penelitian seperti yang ditunjukkan pada Tabel 3 .

Gerakan tanah yang terjadi disekitar jalan kereta api Km.110 karena dipicu oleh infiltrasi air hujan dan getaran dari lalu lintas kereta api. Secara geologi jenis batuan daerah penelitian terdiri dari lempung, pasir dan breksi. Infiltrasi air hujan akan mengaktifkan batulempung yang berfungsi sebagai bidang gelincir. Aliran air permukaan (water table) mengalir dari lereng perbukitan sebelah Barat menuju jembatan kereta api sampai dengan tebing lembah sebelah Timur. Pada daerah patahan sepanjang kaki bukit di sebelah Barat (jalan kereta api Km $110+2 / 7$ ) berderet mata air pada batu pasir dan breksi. Air dari deretan mata air tersebut mengalir ke saluran kiri jalan kereta api serta mengalir melalui pipa-pipa dan melalui box culvert di bawah jembatan kereta api. Adanya kerusakan pada sistem drainase (pipa-pipa dan box culvert) yang retak dan hancur, mengakibatkan aliran air terhambat sehingga air merembes ke lapisan tanah/batuan yang terdapat dibawah jembatan kereta, sehingga lapisan tanah menjadi jenuh air. Adanya lapisan yang jenuh air mengindikasikan bahwa terdapat batuan yang kedap air sehingga dapat berfungsi sebagai bidang gelincir. 
Tabel 2. Data Analisis Laboratorium Mekanika Tanah

\begin{tabular}{cccc}
\hline No. & Jenis Batuan & Porositas & Permeabilitas \\
\hline 1. & Batulempung & $54,99 \%$ & $5,39 \times 10^{-7} \mathrm{~cm} / \mathrm{sec}$ \\
\hline 2. & Pasir & $39,65 \%$ & $1,13 \times 10^{-3} \mathrm{~cm} / \mathrm{sec}$ \\
\hline
\end{tabular}

Tabel 3. Nilai Resistivitas Batuan di Daerah Penelitian

\begin{tabular}{lcl}
\hline No. & Resistivitas $(\Omega \mathrm{m})$ & \multicolumn{1}{c}{ Jenis batuan } \\
\hline I. & $1-8$ & Batulempung (padat) \\
\hline II. & $8-13$ & Batulempung pasiran \\
III. & $13-20$ & Pasir \\
IV. & $20-24$ & Lempung (tidak kompak) / tanah timbunan \\
\hline V. & $>24$ & Breksi / Kerikil (kurang padat) \\
\hline
\end{tabular}

Bidang gelincir di daerah penelitian berarah Barat-Timur dengan kemiringan sudut gelincir : 30 - 40 derajat. Bidang gelincir ini berada sekitar 20 meter dari pilar / tiang penguat jembatan kereta api yang berada di sebelah Barat, apabila bidang gelincir ini tidak segera ditangani secepatnya maka akan terjadi pergeseran dan amblasan tanah yang mengarah ke sebelah Barat mendekati pilar / tiang penguat jembatan kereta api. Sehubungan dengan hal tersebut maka perlu dipasang beberapa pondasi tiang pancang pada bidang gelincir ke arah gelinciran / tebing lembah sebelah Timur, dengan kedalaman pondasi tiang pancang menggunakan data kedalaman hasil pengukuran resistivitas.

Indikasi bidang gelincir yang dipicu oleh air hujan dapat dilihat pada penampang resistivitas lintasan 3 (Gambar 3a) dan penampang resistivitas lintasan 4 (Gambar $3 b)$. Bidang gelincir terdapat pada lapisan batuan dengan nilai resistivitas: $1-4,83$ $\Omega \mathrm{m}$ yang diindikasikan sebagai batulempung dengan kedalaman: 6 - $15 \mathrm{~m}$. Pada penampang resistivitas lintasan 3 (Gambar 3) terdapat indikasi struktur patahan, struktur ini berfungsi sebagai salah satu celah masuknya air ke dalam tanah/batuan sehingga dapat mempercepat terjadinya proses pelapukan dan mempercepat aktifnya batulempung sebagai bidang gelincir.

Lapisan batuan diatas bidang gelincir (Gambar 3a dan 3b) yang mengalami pergeseran, yaitu: lempung lembek / lumpur (resistivitas: 14 - $23 \Omega \mathrm{m}$ ), pasir kasar (resistivitas: 8 - $14 \Omega \mathrm{m}$ ). Pergeseran pasir dan tanah timbunan terjadi karena adanya saturasi air pada lapisan tersebut, lapisan tanah yang jenuh air akan mengakibatkan daya ikat tanah melemah sehingga terjadi pergeseran batuan. Gerakan tanah di tebing lembah ini termasuk dalam zona gerakan tanah lama, daerahnya cukup luas, tebing mahkota gerakan tanah di dekat daerah jalan desa memanjang dari Km.110 $+5 / 7$, tinggi tebing mahkota gerakan tanah mencapai $6 \mathrm{~m}$ dengan kemiringan $>60$ derajat. Aliran air dilokasi penelitian tidak beraturan dan terjadi kejenuhan air pada tanah, hal ini terjadi karena box culvert bergeser dan roboh akibat bergesernya pilar pondasi tiang pancang bor pile di dekat tebing lembah. Gerakan tanah di lokasi penelitian bergerak dengan gerakan pelan - cepat, jenis gerakan dominan rotational slide kemudian berkembang menjadi translation slide. 


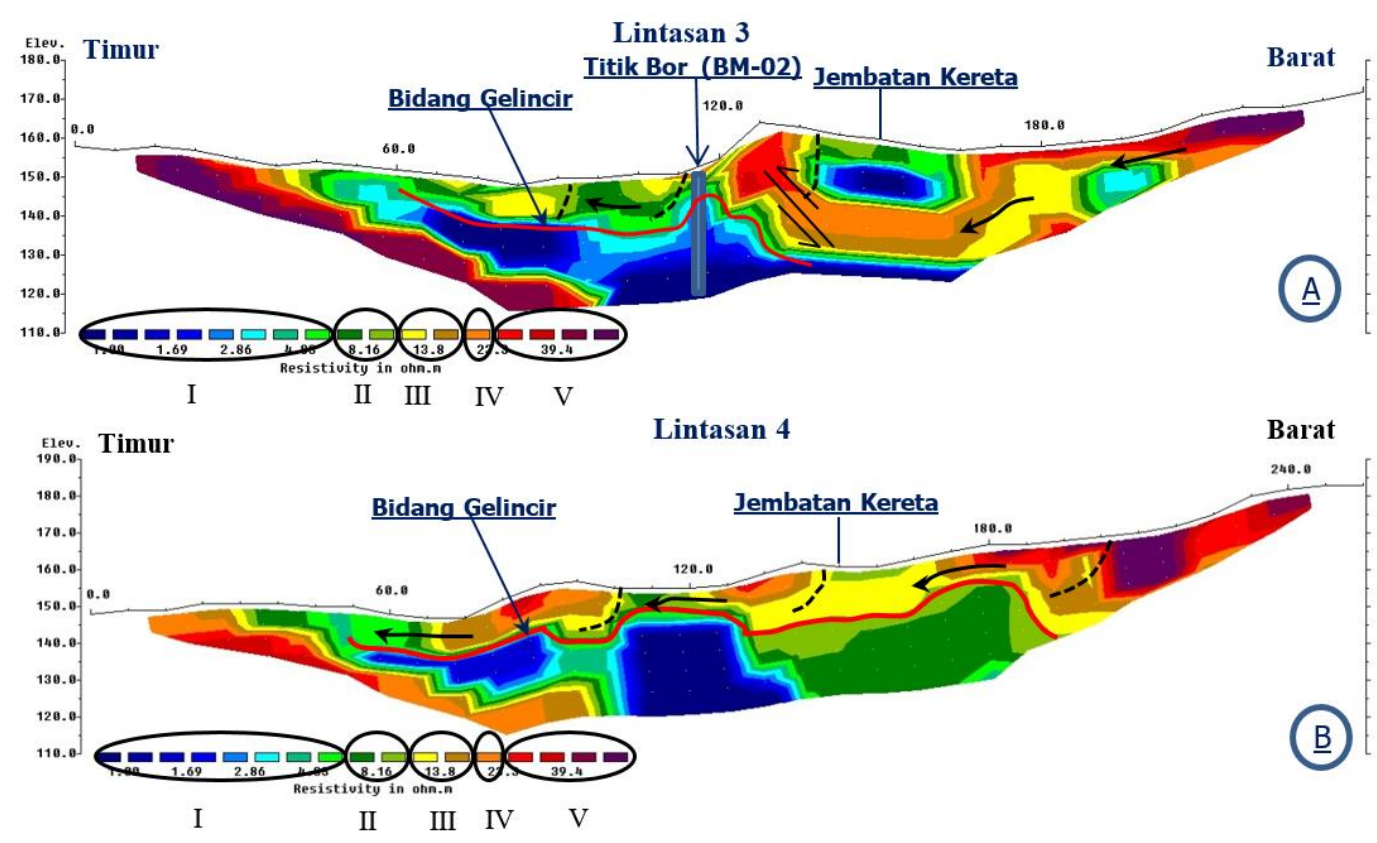

Gambar 3. (A) Penampang Resistivitas Lintasan 3, (B) Penampang Resistivitas Lintasan 4. Jenis Batuan, I: Batulempung (padat), II: Batulempung pasiran, III: Pasir, IV: Lempung (tidak padat) / tanah timbunan, V: Breksi /kerikil (tidak padat)

Gambar 4a dan 4b menampilkan penampang resistivitas lintasan 1 dan 2 dengan arah lintasan sejajar dengan jalan kereta api. Lokasi ini merupakan daerah aliran pembuangan air yang berasal dari pemukiman dan jalan kereta. Bidang gelincir di lokasi ini terdapat pada permukaan batu lempung dengan nilai resistivitas: 1 - 4,83 $\Omega \mathrm{m}$. Batulempung ini dapat berfungsi sebagai bidang gelincir karena dipicu oleh aliran air dari pemukiman serta faktor air hujan. Gerakan tanah ini termasuk ke dalam zona gerakan tanah lama, terjadi pada wing wall / tebing tubuh jalan kereta daerah pangkal jembatan arah Bandung. Jenis gerakan tanah dominan rotational slide diikuti amblesan dan retakan, gerakannya pelan - cepat. Mahkota longsoran terdapat di dekat tubuh jalan kereta, dan ujung gerakan tanah berada di jalan desa. Tanah atau batuan diatas bidang gelincir yang bergeser/bergerak adalah tanah lempung pasir kerikil (resistivitas: $>24 \Omega \mathrm{m}$ ) yang merupakan tanah timbunan dan rombakan yang bersifat kurang padat.

Berdasarkan penampang resistivitas, kedalaman bidang gelincir bervariasi mulai kedalaman > $6 \mathrm{~m}$ dengan jenis batuannya Batulempung. Batulempung memiliki kadar air yang kecil, hal ini dapat dilihat dari nilai kekerasan tanah dengan SPT > 60 N. Jika diklasifikasikan berdasarkan tingkat kekerasan, batulempung termasuk dalam klasifikasi lapisan batuan keras/padat [13]. Air yang merembes ke dalam tanah dipengaruhi oleh porositas, permeabilitas, kemiringan lereng, jenis tanah / batuan, vegetasi dan curah hujan. Permeabilitas dan Porositas memiliki hubungan yang erat keduanya bergantung pada jumlah ruang kosong. Berdasarkan hasil analisis laboratorium mekanika tanah, batulempung memiliki porositas tinggi: $54,99 \%$ dan permeabilitas sangat kecil: 5,39 x $10^{-7} \mathrm{~cm} /$ detik. Meskipun 
batulempung memiliki porositas tinggi, tetapi jarak antar butir sangat sempit (porositas bebatuan tidak saling berhubungan), sehingga air tidak bisa melewatinya.
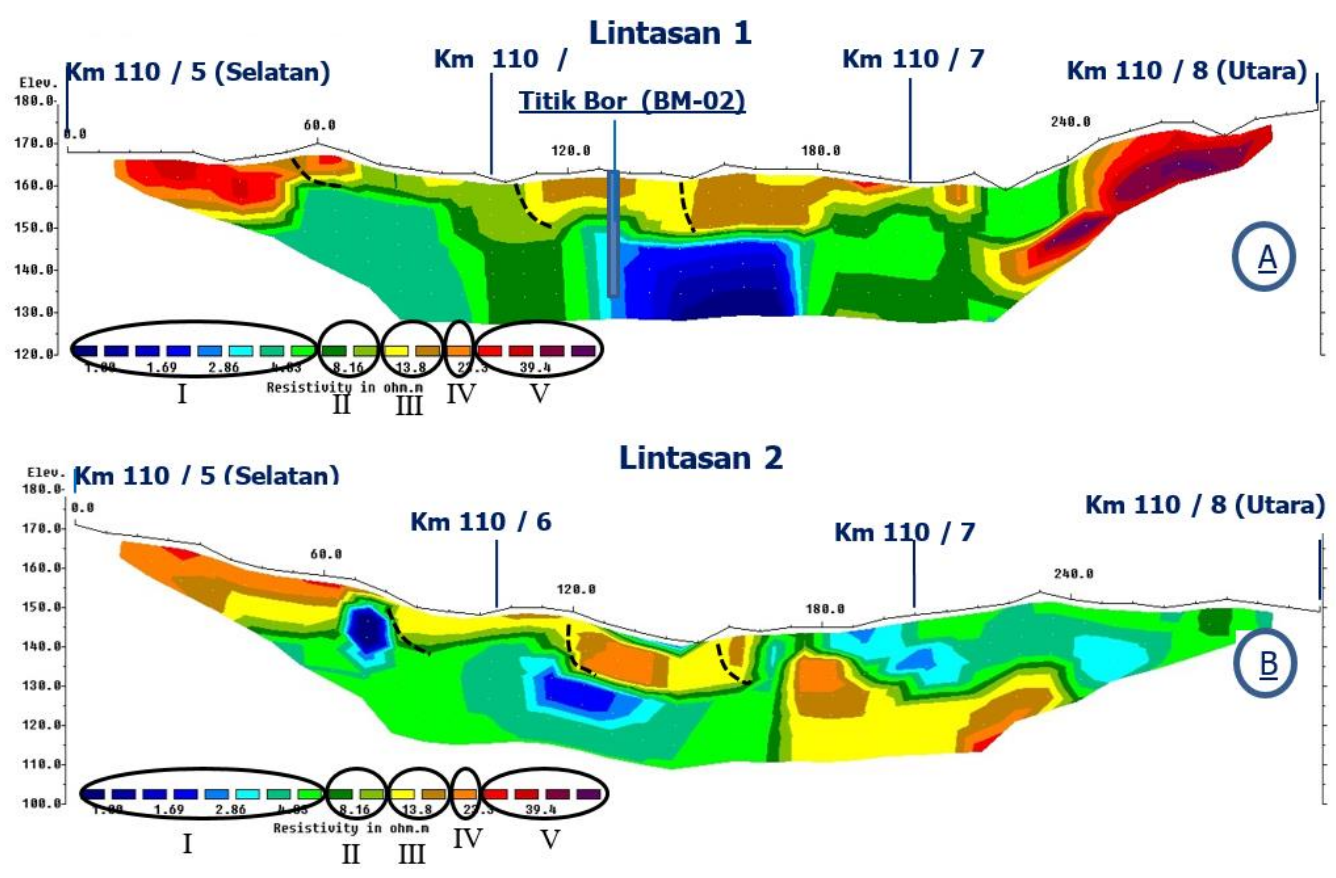

Gambar 4. (A) Penampang Resistivitas Lintasan 1, (B) Penampang Resistivitas Lintasan 2. Jenis Batuan, I: Batulempung (padat), II: Batulempung pasiran, III: Pasir, IV: Lempung (tidak padat) / tanah timbunan, V: Breksi /kerikil (tidak padat)

\section{Kesimpulan}

Bidang gelincir di daerah penelitian memiliki sudut kemiringan 30 - 40 derajat dengan arah gelincirnya ke arah Timur menuju tebing lembah. Bidang gelincir ini tegak lurus pilar jembatan kereta api (tebing mahkota longsoran), oleh karena itu jika tidak ditangani dengan cepat maka diperkirakan pilar jembatan kereta api ini akan amblas dan memutus transportasi kereta api Bandung - Jakarta.

Berdasarkan parameter fisika batuan, bidang gelincir terdapat pada permukaan batulempung dengan nilai resistivitas $1-5 \Omega \mathrm{m}$, porositas $54,99 \%$ dan permeabilitas $5,39 \times 10^{-7} \mathrm{~cm} / \mathrm{sec}$. Batulempung meskipun memiliki porositas tinggi $(54,99 \%)$ tetapi ruang antar butirnya tidak berhubungan sehingga tidak bisa menyimpan air, oleh karena itu maka nilai permeabilitasnya kecil $\left(5,39 \times 10^{-7}\right.$ $\mathrm{cm} / \mathrm{sec}$ ). Batulempung bersifat impermeabel / kedap air, sehingga air yang sampai dipermukaan batulempung tidak akan diteruskan lagi ke lapisan dibawahnya, akibatnya batuan yang berada diatasnya akan mudah jenuh air sehingga terjadi gerakan tanah / longsor. Permukaan batulempung yang menjadi bidang gelincir memiliki sifat yang berbeda dengan tanah lempung yang ada di dekat permukaan. Batulempung di daerah penelitian merupakan material yang padat / keras dengan nilai kekerasan tanah standard penetration test $(\mathrm{SPT})>60 \mathrm{~N}$, sedangkan tanah lempung merupakan material tidak padat / lunak dengan nilai kekerasan tanah SPT $6 \mathrm{~N}$. 


\section{Ucapan Terima Kasih}

Penulis mengucapkan terima kasih kepada Rektor Unpad yang telah membantu mendanai penelitian ini melalui skema HIU-RFU Unpad serta Kepala PT Kereta Api Indonesia (KAI) Daop 2 Bandung yang telah banyak membantu dalam perizinan dan operasional kegiatan penelitian ini.

\section{Daftar Pustaka}

1. R.N. Chowdhury, Geotechnical Slope Analysis, Elsevier Amsterdam (2010), p.317.

2. K. Sassa, K and P. Canuti, Landslides Disaster Risk Reduction, SpringerVerlag Berlin Heidelberg (2009).

3. B.D. Malamud, D. L. Turcotte, F. Guzzetti and Reichenbach, Journal of Earth Surface Processes and Landforms (2004), p. 687-711.

4. Z. Zakaria, L.H. Jihadi, Z.S. Sabila and A.W. Oscar, Proceedings of The 2nd International Conference Hanoigeo Hanoi, Vietnam (2015), p. 365-367.

5. PVMBG, Peta Zona Kerentanan Gerakan Tanah, Purwakarta, Jawa Barat, Pusat Vulkanologi dan Mitigasi Bencana Geologi, Bandung (2008).

6. P.H. Silitonga, Peta Geologi Lembar Bandung, Pusat Penelitian dan Pengembangan Geologi (1973).

7. S. Carpentier, M. Konz, R. Fischer, Anagnostopoulos G, Meusburger M and Schoeck K, Journal of Applied Geophysics, Vol. 83 (2012), p. 46-56.

8. J. Gance, J.P. Malet, R. Supper, P. Sailhac, D. Ottowitz and B. Jochum, Journal of Applied Geophysics, Vol.126 (2016), p. 98-115.

9. S. Uhlemann, P.B. Wilkinson, J.E. Chambers, H. Maurer, A.J. Merritt, D.A. Gunn and P.I. Meldrum, Journal of Applied Geophysics, Vol. 121 (2015), p. 93-105.

10. W. Daily, A. Ramirez, A. Binley and D.J. LeBrecque, The Leading Edge, Vol. 23 (2004), p. 5.

11. W.M. Telford, L. P. Geldart and R. E. Sheriff, Applied Geophysics 2 Edition, Cambridge University Press, Cambridge (2004), p 535-7.

12. M. H. Loke, Rapid 2D Resistivitas and IP Inversion Using the Least-Squares Method, Geotomo Software, Malaysia (2004), p 11-36.

13. K. Terzaghi, B. Ralph, Peck, and Gholamreza Mesri, Soil Mechanics in Engineering Practice, John Wiley \& Sons, Inc. Newyork (1996). p. 34. 